most commonly administered antifungal agent was amphotericin B. Details of steroid therapy and the outcomes are presented in Table $1[3,7,8,9,10,11]$. Increased susceptibility to infection might be a drawback for prolonged corticotherapy. However, neither Candida reactivation nor other new opportunistic infections have been reported [3].

Candida-related IRIS has been rarely reported in children. Early recognition and appropriate management of IRIS might prevent unnecessary diagnostic procedures, antibiotic usage, and chemotherapy delays.

\section{Acknowledgment}

This work was partially presented at the 9th Biennial Childhood Leukemia Symposium, Prague, Czech Republic, 28-29 April 2014.

Keywords: Leukemia, Febrile neutropenia, Candida, Immune response inflammatory syndrome

Anahtar Sözcükler: Lösemi, Febril nötropeni, Candida, İmmün yanıt enflamatuvar sendromu

Conflict of Interest: The authors of this paper have no conflicts of interest, including specific financial interests, relationships, and/ or affiliations relevant to the subject matter or materials included.

\section{References}

1. Rammaert B, Desjardins A, Lortholary 0 . New insights into hepatosplenic candidosis, a manifestation of chronic disseminated candidosis. Mycoses 2012;55:74-84
2. Fleischhacker M, Schulz $\mathrm{S}$, Jöhrens $\mathrm{K}$, von Lilienfeld-Toal M, Held T, Fietze E, Schewe C, Petersen I, Ruhnke M. Diagnosis of chronic disseminated candidosis from liver biopsies by a novel PCR in patients with haematological malignancies. Clin Microbiol Infect 2012;18:1010-1016.

3. Legrand F, Lecuit M, Dupont B, Bellaton E, Huerre M, Rohrlich PS, Lortholary 0 . Adjuvant corticosteroid therapy for chronic disseminated candidiasis. Clin Infect Dis 2008;46:696-702.

4. Manabe YC, Campbell JD, Sydnor E, Moore RD. Immune reconstitution inflammatory syndrome: risk factors and treatment implications. J Acquir Immune Defic Syndr 2007;46:456-462.

5. Karthaus M, Huebner G, Geissler RG, Heil G, Ganser A. Hepatic lesions of chronic disseminated systemic candidiasis in leukemia patients may become visible during neutropenia: value of serial ultrasound examinations. Blood 1998;91:3087-3089.

6. Pestalozzi BC, Krestin GP, Schanz U, Jacky E, Gmür J. Hepatic lesions of chronic disseminated candidiasis may become invisible during neutropenia. Blood 1997;90:3858-3864.

7. Bayram C, Fettah A, Yarali N, Kara A, Azik FM, Tavil B, Tunc B. Adjuvant corticosteroid therapy in hepatosplenic candidiasis-related iris. Mediterr J Hematol Infect Dis 2012;4:e2012018.

8. Conter $C D$, Thiesse $P$, Bienvenu A. Persistent fever and hepatosplenic candidiasis, efficiency of a corticoid therapy. J Mycol Med 2007;17:194197.

9. Chaussade H, Bastides F, Lissandre S, Blouin P, Bailly E, Chandenier J, Gyan E, Bernard L. Usefulness of corticosteroid therapy during chronic disseminated candidiasis: case reports and literature review. J Antimicrob Chemother 2012;67:1493-1495.

10. De Castro N, Mazoyer E, Porcher R, Raffoux E, Suarez F, Ribaud P, Lortholary O, Molina JM. Hepatosplenic candidiasis in the era of new antifungal drugs: a study in Paris 2000-2007. Clin Microbiol Infect 2012;18:185-187.

11. Saint-Faust M, Boyer C, Gari-Toussaint M, Deville A, Poiree M, Weintraub M, Sirvent N. Adjuvant corticosteroid therapy in 2 children with hepatosplenic candidiasis-related IRIS. J Pediatr Hematol Oncol 2009;31:794-796.

\title{
Posttranslational Modifications of Red Blood Cell Ghost Proteins as "Signatures" for Distinguishing between Low- and High-Risk Myelodysplastic Syndrome Patients
}

\author{
Düşük ve Yüksek Risk Miyelodisplastik Sendrom Hastalarını Ayıran "Işaretler" Olarak Kırmızı \\ Kan Hücre Zarı Proteinlerinin Posttranslasyonel Modifikasyonları
}

Klara Pecankova, Pavel Majek, Jaroslav Cermak, Jan E. Dyr

Institute of Hematology and Blood Transfusion, Prague, Czech Republic

To the Editor,

Myelodysplastic syndrome (MDS) comprises a heterogenic group of oncohematological diseases that affect hematopoiesis. Although the precise cause of MDS is unknown, multiple factors are involved, one of the most widely implicated of which is oxidative stress. However, it is unclear whether oxidative stress is a cause of MDS or an effect of other pathological mechanisms.

Red blood cells (RBCs) are the first cells exposed to stress stimuli. They are highly vulnerable to free radical accumulation, which leads to the oxidative stress that induces damage in proteins and 
other biomacromolecules [1]. In MDS, the RBC proteome can be affected by effects of the peripheral blood environment and/or by abnormal processes possibly caused by oxidative stress during hematopoiesis in bone marrow. Therefore, we chose red cell membranes (ghosts) as a model biological material.

Patient characteristics are summarized in Table 1. All individuals tested agreed to participate in the study on the basis of informed consent. All samples were obtained and analyzed in accordance with the Ethics Committee regulations of the Institute of Hematology and Blood Transfusion. The RBCs were isolated from whole blood by differential centrifugation and frozen at $-80^{\circ} \mathrm{C}$. The red cell ghosts were isolated according to the method of Dodge et al. [2]. Proteins were separated using 2D SDS-PAGE followed by silver staining [3]. The gels were digitized and processed using Progenesis SameSpots software. Significantly differing spots $(p<0.05)$ were submitted for protein identification by tandem mass spectrometry coupled to a Nano LC system.

By comparing the high- and low-risk MDS ghost proteomes, we found 22 significantly differing spots that corresponded to 16 unique proteins, particularly spectrin and its interaction partners in the membrane skeleton meshwork (actin, tropomodulin, tropomyosin, ankyrin, protein 4.1). To determine whether the changes were caused by protein expression level alterations or by posttranslational modifications, we analyzed the LC-MS data using Progenesis LC-MS software. No significant changes in

\begin{tabular}{|c|c|c|c|c|c|c|}
\hline Risk & Sample & Diagnosis & Sex & $\begin{array}{l}\text { Sex } \\
(\%)\end{array}$ & $\begin{array}{l}\text { Age } \\
\text { (years) }\end{array}$ & $\begin{array}{l}\text { Median } \\
\text { age }\end{array}$ \\
\hline \multirow{10}{*}{$\begin{array}{l}\text { Low } \\
\text { risk }\end{array}$} & 1 & RCMD & $\mathrm{F}$ & \multirow{4}{*}{40} & 41 & \multirow{10}{*}{61} \\
\hline & 2 & RARS & $\mathrm{F}$ & & 59 & \\
\hline & 3 & RCMD & $\mathrm{F}$ & & 57 & \\
\hline & 4 & RCMD & $\mathrm{F}$ & & 64 & \\
\hline & 5 & RARS & $M$ & \multirow{6}{*}{60} & 62 & \\
\hline & 6 & RA & $\mathrm{M}$ & & 79 & \\
\hline & 7 & RCMD & $M$ & & 51 & \\
\hline & 8 & RCMD & $M$ & & 75 & \\
\hline & 9 & RARS & $\mathrm{M}$ & & 40 & \\
\hline & 10 & RCMD & $M$ & & 67 & \\
\hline \multirow{6}{*}{$\begin{array}{l}\text { High } \\
\text { risk }\end{array}$} & 11 & RAEB-1 & $\mathrm{F}$ & \multirow{4}{*}{67} & 58 & \multirow{6}{*}{63} \\
\hline & 12 & RAEB-2 & $\mathrm{F}$ & & 65 & \\
\hline & 13 & RAEB-2 & $\mathrm{F}$ & & 67 & \\
\hline & 14 & RAEB-2 & $\mathrm{F}$ & & 63 & \\
\hline & 15 & RAEB-2 & $M$ & \multirow{2}{*}{33} & 55 & \\
\hline & 16 & RAEB-1 & $M$ & & 67 & \\
\hline \multicolumn{7}{|c|}{$\begin{array}{l}\text { RCMD: Refractory anemia with multilineage dysplasia, RARS: refractory anemia with } \\
\text { ringed sideroblasts, RA: refractory anemia, RAEB-1: refractory anemia with excess of } \\
\text { blasts type 1, RAEB-2: refractory anemia with excess of blasts type 2, F: Female, M: Male. }\end{array}$} \\
\hline
\end{tabular}

protein expression levels were observed. Therefore, the changes between the low- and high-risk MDS cohorts were caused by protein modifications.

It is well known that RBC function may be radically affected by membrane protein posttranslational modifications. For example, the increased phosphorylation of spectrin, the protein crucial for cytoskeletal stability, worsens the mechanical properties of the RBC membrane [4], and the phosphorylation of protein 4.1 leads to RBC osmotic fragility. Moreover, increased protein 4.1 mobility, suggesting the presence of other modifications, has been observed in MDS patients. The production of abnormal protein 4.1 may result in the dysregulation of spectrin-actin interaction and may cause both RBC shape change and membrane instability [5]. In addition, altered membrane morphology, including holes and thorn-like structures, was described for the RBCs of MDS and acute myeloid leukemia patients [6].

Because the impact of RBC protein modifications is clear, our preliminary data suggest that it might be possible to profile MDS patients according to the type of modification. Such modifications could thus be considered characteristic signatures of MDS or its progression. As such, they might help in the earlier diagnosis and treatment of MDS patients.

\section{Acknowledgments}

This study was supported by the Czech Science Foundation's P205/12/G118 and by a state project (Ministry of Health, Czech Republic) for the conceptual development of the research organization (Institute of Hematology and Blood Transfusion).

\section{Contributors' Statement}

$\mathrm{KP}$ and PM performed research. $\mathrm{KP}, \mathrm{PM}, \mathrm{JC}$, and JED designed the study. JC provided samples. KP, PM, JC, and JED drafted the manuscript. All authors read and approved the final manuscript.

Keywords: Myelodysplastic syndromes, Proteomics, Red blood cell ghosts, Posttranslational modifications, Erythrocytes, Electrophoresis

Anahtar Sözcükler: Miyelodisplastik sendrom, Proteomik, Kırmızı kan hücre zarı, Posttranslasyonel modifikasyon, Eritrosit, Elektroforez

\section{References}

1. Pandey KB, Rizvi SI. Biomarkers of oxidative stress in red blood cells. Pap Med Fac Univ Palacky Olomouc Czech Repub 2011;155:131-136.

2. Dodge JT, Mitchell C, Hanahan DJ. The preparation and chemical characteristics of hemoglobin-free ghosts of human erythrocytes. Arch Biochem Biophys 1963;100:119-130.

3. Chevallet M, Luche S, Diemer H, Strub JM, Van Dorsselaer A, Rabilloud T. Sweet silver: a formaldehyde-free silver staining using aldoses as developing agents, with enhanced compatibility with mass spectrometry. Proteomics 2008;8:4853-4861. 
4. Manno S, Takakuwa Y, Nagao K, Mohandas N. Modulation of erythrocyte membrane mechanical function by beta-spectrin phosphorylation and dephosphorylation. J Biol Chem 1995;270:5659-5665.

5. Ideguchi H, Yamada $Y$, Kondo S, Tamura K, Makino S, Hamasaki N. Abnormal erythrocyte band 4.1 protein in myelodysplastic syndrome with elliptocytosis. Br J Haematol 1993;85:387-392.

6. Majumder D, Banerjee D, Chandra S, Banerjee $S$, Chakrabarti A. Red cell morphology in leukemia, hypoplastic anemia and myelodysplastic syndrome. Pathophysiology 2006;13:217-225.

\title{
Intradiploic Hematoma in a Hemophilic Patient: Hemophilic Pseudotumor of Calvarium
}

\author{
Hemofilik Bir Hastada Intradiploik Hematom: Kraniyumun Hemofilik Psödotümörü
}

\author{
Hakan Hanımoğlu¹, Zafer Başlar² \\ 1 Istanbul Bilim University Faculty of Medicine, Department of Neurosurgery, Istanbul, Turkey \\ 2 Istanbul University Cerrahpaşa Faculty of Medicine, Department of Internal Medicine, Division of Hematology, Istanbul, Turkey
}

To the Editor,

Pseudotumors are results of repeated hemorrhage into soft tissues, the subperiosteum, or a site of bone fracture with inadequate resorption of the extravasated blood. We describe a patient with a huge hemophilic pseudotumor of calvarium, which occurs very rarely.

A 14-year-old boy with mild hemophilia A (FVIII coagulant activity: 5.8\%) without inhibitor presented with epileptic seizure 7 years ago. The patient was known to be hemophiliac from birth after a birth injury and brain damage had occurred. He was mentally retarded and had habitual head-hitting behavior. His family noticed progressively enlarging painless scalp swelling on his head.

There was obvious asymmetry of the head and face (Figure 1, A-3). His neurological examination was normal and radiological investigations did not reveal any other pathology. A computed tomography (CT) scan showed a large lesion with a mass effect over the underlying brain (Figure 1, A-1 and A-2).

Surgery was carried out with coagulation factor replacement (FVIII). During surgery a skin flap was done and the thinned outer table was incised (Figure 1, B-1). Mud-like material and a liquefied clot were evacuated (Figure 1, B-2). The thin and elastic inner wall was not removed to avoid postoperative complications (Figure 1, B-3).

Following surgery, antiepileptic medication was continued and short-term prophylaxis (30 IU/kg, three times a week) was applied for 8 weeks. At the 7-year follow-up of the patient, he was free of seizures and a CT scan of the patient showed that acceptable calvarial remodeling had occurred (Figure 1, C-1 and C-2).

Proximal pseudotumors may destroy the soft tissues, erode the bone, and cause serious vascular and/or nerve damage [1].

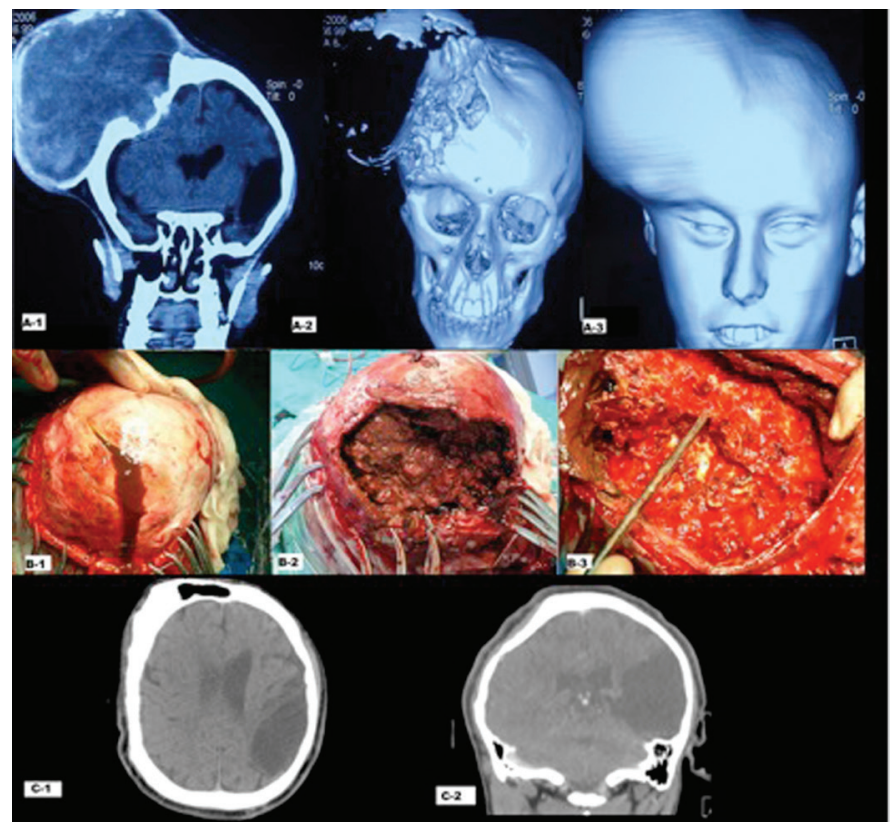

Figure 1. A-1, A-2, A-3: Multidetector computed tomography scan with reconstruction shows large lytic intradiploic lesion with expansion and scalloping of the bony margins; please note that the inner and outer tables are separated and destructed. B-1, B-2, B-3: Intraoperative images; evacuated lesion was mudlike, inner table was protected. C1, C2: Sagittal and coronal computed tomography images after 7 years; good and acceptable remodeling of the calvarium is seen. 